\title{
The Impact of Capital Gains Tax on Investment, Social and Economic Development in Nigeria
}

\author{
Osho, Augustine E. Ph.D \\ Department of Accounting, Achievers University, P. M. B. 1030, Owo, Nigeria \\ Ajibola, Isaac Olushola \\ Department of Accounting, Achievers University, P. M. B. 1030, Owo, Nigeria \\ Omolola, Ramat Abiodun \\ Department of Accounting, Achievers University, P. M. B. 1030, Owo, Nigeria
}

\begin{abstract}
The study examined the impact of capital gains tax on investment, social and economic development in Nigeria. Secondary data from the Federal Inland Revenue Service (FIRS) Bulletin and the Central Bank of Nigeria (CBN) Statistical Bulletin for the period 2007 to 2017 were utilized in the study using multiple regression analysis technique and Pearson product moment correlation to measure the relationship between the independent and the dependent variables. Findings revealed that capital gains tax has positive significant impact on investment, social and economic development in Nigeria but the level of significance is quite low. It is therefore recommended that government should increase the capital gains tax (CGT) rate, but not beyond tolerable limit so as to avoid dissention and maximize the revenue accruable to government to boost gross domestic products. Furthermore, government is advised to strive to attain an optimal CGT rate level which should increase revenue to government without negatively affecting CGT.
\end{abstract}

Keywords: Capital Gains Tax; Economic Development, Exchange Rate; Gross Domestic Product, Inflation Rate, Investment, Social

DOI: $10.7176 / \mathrm{EJBM} / 11-2-04$

\section{Introduction}

Recently, the Nigerian government embarked on tax drive as part of her several strategies to shore-up her revenue and reduce dependence on oil. This came after the country, the biggest economy in Africa slumped into recession. The whole episode came as a rude shock to many who otherwise thought that the economy was robust and strong enough to withstand certain economic pressures and disruptions. The country since the discovery of crude oil had forsaken other sectors and relied on the 'black gold' as her major source of foreign exchange. The negative practice had opened-up the fabrics of the economy to price imbalances and fluctuations in the international oil market, which had impacted on investment, social and economic development. In 2015, the price of crude oil fell to below $\$ 30$ per barrel throwing the whole economy into recession due to her about 80 per cent dependence.

Today, the nation is officially out of recession, thanks to the fiscal and monetary policies deployed by government, including the deliberate diversification of the economy which had directly impacted on investment and economic development. Most importantly, government determined to harness the potentials of the more sure sources of revenue such as taxes from the non-oil sector. It is therefore important to examine the extent of contribution of the tax system, especially the component that deals with gains from transfer of investments and assets.

The Oxford Advanced Learner's Dictionary defines 'tax' as 'money that has to be paid to government so that it can pay for public services'. Henry (1997) defines tax as 'monetary charge imposed by the government on persons, entities or property, levied to yield public revenue. The Public Finance General Directorate (2009) identified that taxation is for the purpose of maintenance of public force and administrative expenses. Miller and Oats (2006) supported stating that taxation is required to fund public expenditure.

According to Adam smith in his famous book 'Wealth of Nations' published in 1776 (Bhatia, 2002), the four principles or cannons of taxation which still holds today in government's fiscal policy formulation are: cannon of equality or ability, cannon of certainty, cannon of convenience, and cannon of economy (Kulkami, 2001; AL-Robeidi, 2000 \& Sundhmaram \& Andley, 2003). The Nigerian tax system dwells on these principles and aims to utilize tax revenues in a way that maximally benefit the citizenry, while also striving to improve on the cannons with strategically formulated policies. As stated by the Presidential Committee on National Tax Policy (2008), the tax system should only cause minimum distortion in the economy, but ensure overall good. Tax policies must be formulated in such a way that could be easily complied with and not cause dissention. It should promote investment and economic development. Consequently, this research work aims to assess the impact of Capital Gain Tax (CGT) on investment, social and economic development in Nigeria between 2007 
and 2017.

\subsection{Literature Review \\ 2.1.1 Concept of Capital Gains Tax}

Capital Gains Tax Act CAP C1 of the Laws of the Federation of Nigeria (LFN) 2004 (as amended), states that Capital Gains may be defined as gains arising from increases in the market value of capital assets, to a corporate body or person who does not habitually offer them for sale, and in whose hands they do not constitute stock-intrade. One could say it is the profit accruing from increases in the market value of assets, to an individual or organization who does not usually deal in such product for sale, and in whose hands they do not constitute inventory. Capital Gains Tax on its part is the compulsory payment imposed on the gains arising from the sale or realization of such assets.

CGT refers to the tax imposed on capital gains, which is the profit realized on the sale of a noninventory assets. The most common capital gains are realized from the sale of stocks, bonds, precious metals, and property. Taxes are charged by the state over the transactions, dividends and capital gains on the stock market. However, these fiscal obligations may vary from jurisdiction to jurisdiction. According to ICAN (2014), Capital Gains Tax is the tax imposed on gains arising out of the ownership of a capital asset changing hands, either by exchange, transfer, sales or gift. It is the tax that would be imposed on any benefit that arises as a result of selling or disposing an item that constitutes the definition of a chargeable asset. Capital Gains Tax is chargeable on the total amount of the chargeable gains arising after deducting allowable expenses on the disposal of Chargeable assets, in a year of assessment. It is the tax that one is mandated to pay on the profit one receives when one sells an asset or investment (PML, 2017). The Act was enacted in 1967 and came into effect 1967/68 probably to provide additional financing to government to fund the Civil war.

In Nigeria, capital gains tax is charged at the rate of $10 \%$ on the gains accruing from the sale of a chargeable asset. Under the provision of the Capital Gains Act, tax liability will arise on actual year basis when a chargeable asset is disposed; the rate of tax is 10 per cent (Ojo, 2009). Capital Gains Tax is chargeable on the total amount of the chargeable gains arising after deducting allowable expenses on the disposal of Chargeable assets, in a year of assessment (ICAN, 2014).

\subsubsection{Principles of Chargeable Asset}

In line Capital Gains Tax Act CAP C1 of the Laws of the Federation of Nigeria (LFN) 2004 (as amended), chargeable assets are assets whose disposal could result in a chargeable gain, examples including:

i Options, debts and incorporeal properties;

ii Currencies other than the Nigerian Naira

iii All qualifying capital expenditures

\subsubsection{Principles of Chargeable Gains}

Section 3, CGT Act defined chargeable assets as meaning all forms of property, whether situated in Nigeria or not and including:

(a) Options, debts and incorporeal property generally;

(b) Any currency other than Nigerian currency; and

(c) Any form of property created by the person disposing of it, or otherwise coming to be owned without being acquired;

(d) Stock and shares of every description (excluded from chargeable assets with effect from 1/1/98).

In respect of assets outside Nigeria and

(i) Disposed by non-resident individual, or

(ii) Trustee of any trust or settlement, or

(iii) A company whose activities are managed and controlled outside Nigeria

CGT is chargeable on that part of the gains (if any) received or brought into Nigeria when they are so dealt with (Section 4). This is what is termed 'remittance bases. Capital loss on disposal of any asset is not deductible from capital gains on disposal of any other asset even if both are of the same type (Section 5).

\subsubsection{Principles of Chargeable Person}

A chargeable person is one who deals in a chargeable asset whom could be a limited liability company or an individual (Ojo, 2009). This is one who has transacted in a chargeable asset whom could be an individual or a corporate entity. Such entity is required by the tax law to remit his tax to the Federal Inland Revenue Service if a company and the State Board of Internal Revenue if an individual. The management of the Capital Gains Tax Act with respect to corporate entities, individuals resident in the Federal Capital Territory (FCT) and Nonresident Individuals (Individuals outside Nigeria), is placed under the administration of the Federal Inland Revenue Service (FIRS). This is with regards to returns, assessments, appeals, collections, recovery and repayments, offences and penalties as well as litigations and the management of the Act with respect to individuals (except Non-residents), is placed under the administration of the States' Board of Internal Revenue (ICAN, 2014) 


\subsubsection{Principles of Disposal}

When you sell or otherwise dispose of an asset it's called a capital gains tax (CGT) event. This is the point at which you make a capital gain or loss. There are other CGT events, such as the loss or destruction of a CGT asset or creating contractual or other rights (Australian Taxation Office, 2018). According to Ojo (2009), an asset may be said to have been disposed where a capital sum is derived from a sale, lease, transfer, an assignment, a compulsory acquisition or any other disposition of asset. Disposal could also be deemed to have taken place even where no asset was acquired by the person paying such capital sum. The following are the characteristics of disposal:

i. any sum received representing compensation for loss of job or office;

ii. any amount received under insurance policy, and the risk of any kind of damage or injury to or loss or depreciation of assets;

iii. any sum received for not exercising right;

iv. any sum derived as consideration for use or exploitation of an asset;

v. any sum received in connection with or arises by virtue of any trade, business, profession or vocation.

Acquisition/disposal takes effect on the date of the contract to acquire/dispose of the asset or on a date at which there is an enforceable right to acquire or a binding duty to dispose of the asset or any right or interest therein

\subsubsection{Principles of Arms-length Transaction and Connected Persons}

In practice, some persons are regarded as being so closely knit with each other that they have to be handled as the same person, or that transactions between them need to be treated specially from those 'at arm's length'. These persons are referred to as 'connected persons'. Transactions between such persons may be regarded as artificial or fictitious for the purpose of determining the tax liability arising therefrom. This implies that the tax office can make adjustments as it considers necessary to normalize the reduction of tax liability that could otherwise result from such transactions.

In line Capital Gains Tax Act CAP C1 of the Laws of the Federation of Nigeria (LFN) 2004 (as amended), where a person acquires an asset and the person making the disposal is connected with him, the person acquiring the asset and the person making the disposal shall be treated as parties to a transaction made otherwise than by way of a bargain at arm's length (Section 23 (1\& 2). The consideration shall be disregarded if less than the market value and the consideration shall be deemed to be the market value.

\subsubsection{Determining Connected Persons (Section 24)}

(a) An individual is connected with his/her spouse and with his/her relatives and their spouses;

(b) A trustee of a settlement is connected with the settlor of that settlement, and with any person connected with the settlor;

(c) A partner is connected with the person with whom he is in partnership and with the spouse or relative of that person;

(d) A company is connected with another company if -

(i) The same person controls both, or

(ii) One is controlled by a person who has control of the other in conjunction with persons connected with him, or

(iii) A person controls one company and persons connected with him control the other or

(iv) The same group of persons controls both, or

(v) The companies are controlled by separate group which can be regarded as the same by interchanging connected persons.

(e) A company is connected with another person who (either alone or with persons connected with him) has control of it; and

(f) Persons acting to secure or exercise control of a company are treated in relation to that company as connected with each other and with any other person acting on the direction of any of them to secure or exercise such control. 'Relative' is also defined in the Act as meaning, brother, sister, ancestral or lineal descendant.

\subsubsection{Principle of Consideration}

Consideration for asset acquired/disposed of shall be deemed to be equal to the market value of the asset where any person acquires the asset:

(a) Otherwise than by way of a bargain made at arm's length;

(b) Wholly or partly for a consideration that cannot be valued or in connection with his own or another's loss of office or employment or diminution of emolument, or otherwise in consideration for or recognition of services or past services;

(c) As trustee for creditors of the person making the disposal (Section 7 (1)).

Where a person donates an asset acquired by him by way of a gift (not being an acquisition on devolution on death) or otherwise, the person receiving the donation shall, for all purposes of the Act, so far as it relates to the interest taken by him, be deemed to have acquired the asset: 
(i) In a case where the amount of the consideration for which the asset was last disposed of by way of a bargain made at arm's length is ascertainable, for a consideration equal to that amount; and

(ii) In any other case, for a consideration equal to the market value of the asset on the date of that disposal; and in this subsection "gift" does not include a donation mortis causa (Section 7 (2)).

The conveyance or transfer by way of security of an asset (including a retransfer on redemption of the security), shall not be treated for the purposes of the Act as involving any acquisition or disposal of the asset (Section 7 (4)).

Where a person entitled to an asset by way of security or to the benefit of a charge or encumbrance on an asset deals with the asset for the purpose of enforcing or giving effect to the security, charge or encumbrance his dealings with it shall be treated for the purposes of the Act as if they were done through him as nominee of the person entitled to it subject to the security, charge or encumbrance; and this subsection shall apply to the dealings of any person appointed to enforce or give effect to the security, charge or encumbrance as receiver and manager or judicial factor as it applies to the dealings of the person entitled as aforesaid (Section 7 (5).

An asset shall be treated as having been acquired free of any interest or right by way of security subsisting at the time of any acquisition of it, and as being disposed of free of any such interest or right subsisting at the time of the disposal; and where an asset is acquired subject to any such interest or right the full amount of the liability thereby assumed by the person acquiring the asset shall form part of the consideration for the acquisition and disposal in addition to any other consideration (Section 7 (6)).

Where an asset is acquired by a creditor in satisfaction of his debt or part thereof, the asset shall not be treated as disposed of by the debtor or acquired by the creditor for a consideration greater than its market value at the time of the creditor's acquisition of it, and if a chargeable gain accrues to the creditor on a disposal by him of the asset the amount of the chargeable gain (where necessary) shall be reduced such that it will not exceed the chargeable gain which would have accrued if he had acquired the property for a consideration equal to the amount of the debt or that part thereof (Section 7 (7)).

Any amount that can be treated as income or profits for the purposes of the Income Taxes Acts shall be excluded from the consideration for a disposal of assets for capital gains tax computation (Section 13)).

\subsubsection{Assets Exempted From Capital Gains Tax}

According to Nairametrics (2013), the following assets are exempted from Capital Gains Tax

1. Gains on Stock, shares, and other government securities such as treasury bonds, premium bonds and savings certificates.

2. Ecclesiastical, charitable or educational institutions of a public character.

3. Any statutory or registered friendly society.

4. Any co-operative society registered under the Co-operative Societies Law of any State in the Federation of Nigeria.

5. Any trade union registered under the Trade Union Act.

6. Gains on a decoration awarded for gallantry conduct.

7. Gains accruing to statutory bodies.

8. Gains arising from acquisitions, mergers, or takeovers provided that no cash payment is made in respect of the shares acquired.

9. Gains on policies of assurance or deferred annuity unless the beneficiary is not the original Owner as in an estate.

10. Compensation for a wrong or injury of libel, slander, enticement, loss of office in a personal or professional capacity.

11. Gains from the main or only private residence of the individual provided that the area does not exceed one acre.

12. Gains on private vehicles.

13. Gains on any asset used for the purpose of a trade or business provided that the gain is used for replacing the old asset sold.

14. Gains from a provident or retirement benefit scheme.

15. Unit holders of a Unit Trust provided the proceeds are not reinvested.

16. Any diplomatic body.

\subsubsection{Relationship between Capital Gains Tax, Investment, Social and Economic Development}

Flowing from the foregoing, capital gains tax which is imposed in Nigeria at the rate of 10 per cent may be defined as tax charged on gains arising from increases in the market value of capital assets to a person or corporate body, who does not habitually offer them for sale and in whose hands they do not constitute stock-inTrade. Tax generally is a fiscal measure that government employs to stimulate the economy. Alongside its 'monetary policy' counterpart, both are powerful tools which government adopts to stir the economy of the country in whatever direction they deem fit.

Capital gains tax has a way of affecting investment, social and economic development. Naturally, no one 
would pay tax if given the opportunity. People pay tax because they are required or mandated by law. This is because tax reduces the disposable income of people and return on equity of investors. The implication being reduction in the money that penetrates to services the economy in the way of purchase of goods and services which adversely affect investment and economic growth. On the other way, reduction in capital gain would increase disposable income and return on equity which would translate to increase investment and boost the economy.

Conversely, Capital gains tax is a source of public revenue to government. The higher the rate, the higher the government revenue, which usually would translate to more robust purse and ability to carry out capital projects and other public expenditure. The whole process can be used to stimulate and directly impact the economy via employment creation, investment creation etc.

Disposed shares usually suffer CGT and service costs, consequently discouraging the frequency at which investors sell their shares. Reducing capital gains taxes fires-up the disposal or realizations of stocks as investors and business persons cash-in long-term capital gains. Consumer spending increases as capital gains realizations, after tax, are spent or saved. CGT reduces the rate at which the shares exchange hands thereby reducing the rate at which funds flows to households. A tax on capital income increases the "hurdle rate" of return or "service price" that an asset must earn to be worth investing in. These growth effects or macro-economic effects of cuts in the taxation of capital are not allowed for in the revenue estimating process (Fasina \& Adegbite, 2016).

CGT reduction benefits the high income tax-payers to low income tax payers. A tax reduction on capital gains would mostly benefit very high income taxpayers who are likely to save most of any tax reduction. A temporary capital gains tax reduction possibly could have a negative impact on short-term economic growth (Fasina \& Adegbite, 2016).

The asymmetries in the tax system may discourage entrepreneurs from taking risk (Pınar, 2012). CGT may create another burden of taxation on entrepreneurs. Asymmetric taxation of capital gains and losses (in which gains are taxed more heavily than losses) may become a serious issue for entrepreneurs.

\subsubsection{Inverse Relationship between Capital Gains Tax and Investment Social and Economic Development 2.1.11a Need to find a balance}

\section{Model: figure 1}

Investment, Social \& Economic Dev (GDP)

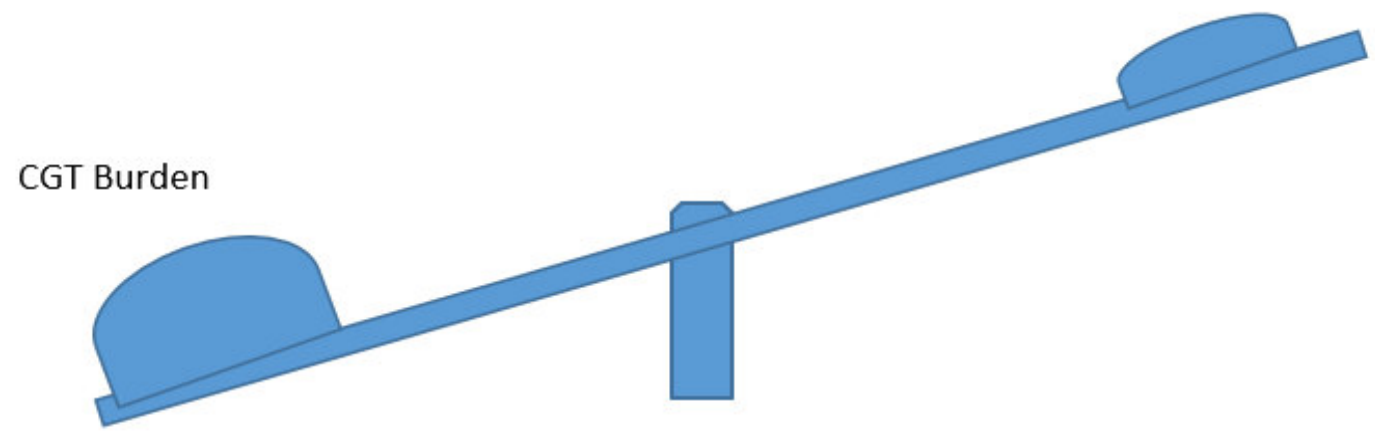

\subsubsection{1b Need to find a balance/ an optimal level}

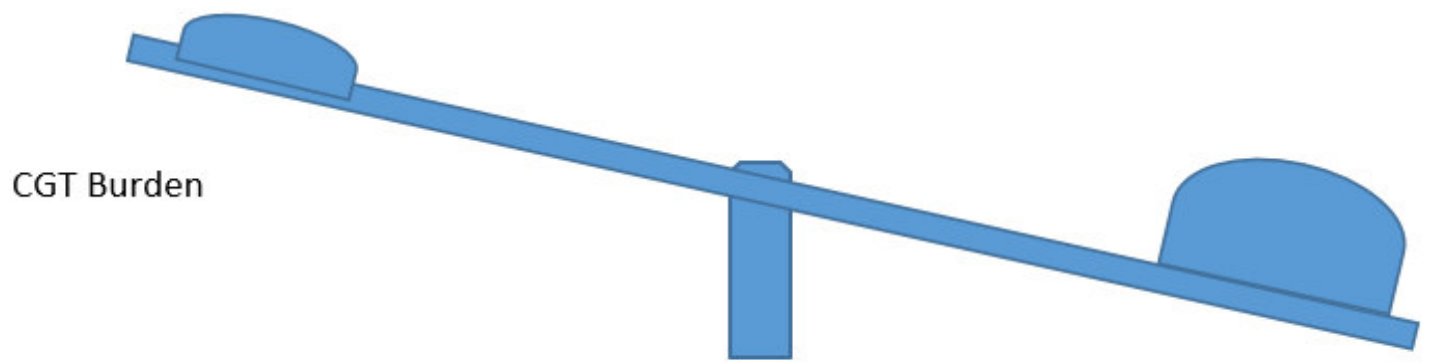

Investment, Social \& Economic Dev (GDP)

Source: Researchers' Inverse Relationship between Capital Gains Tax and Investment, Social and Economic Development Model 


\section{Figure 2}

CGT

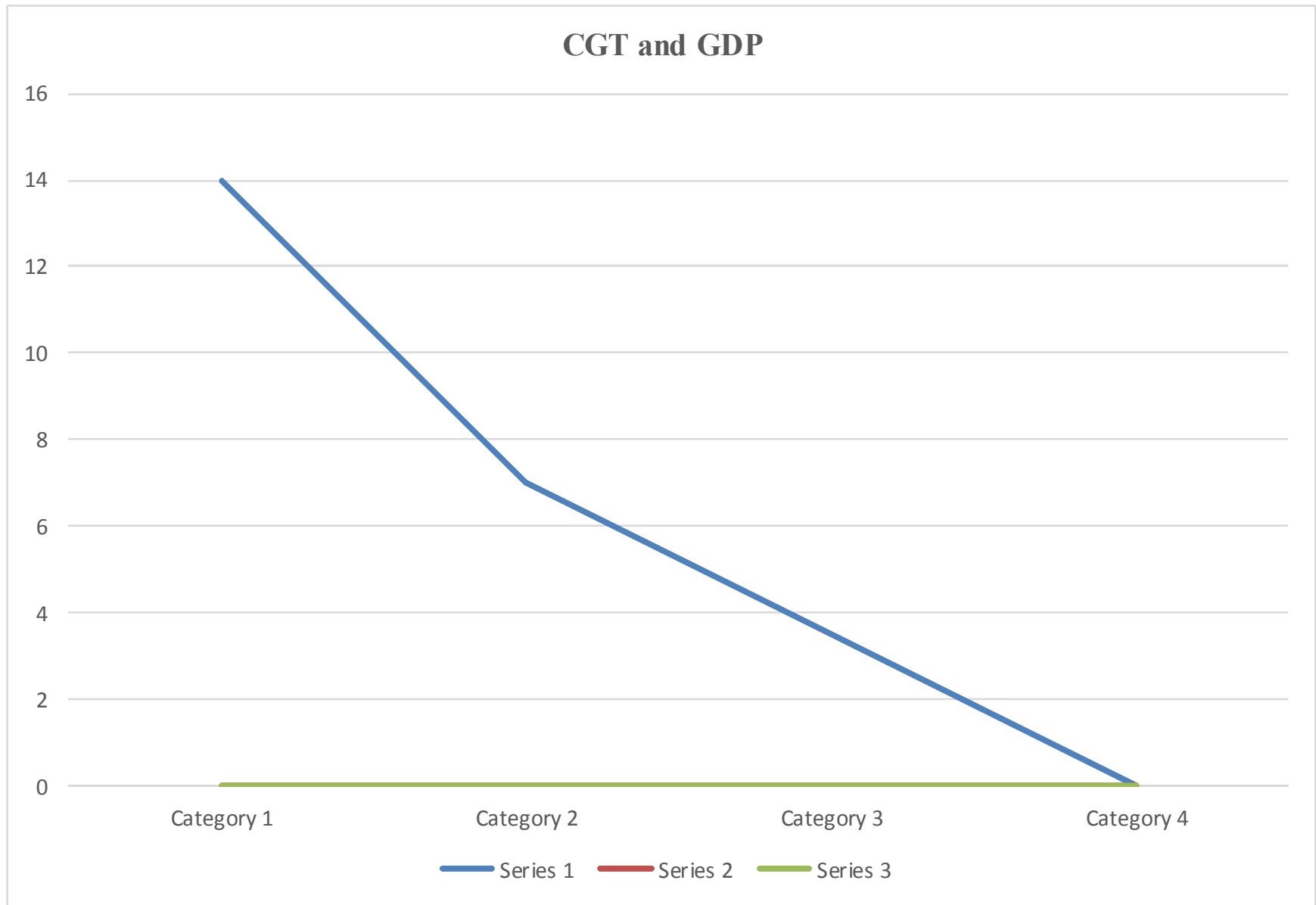

Source: Researchers' Relationship between Capital Gains Tax and Gross Domestic Products

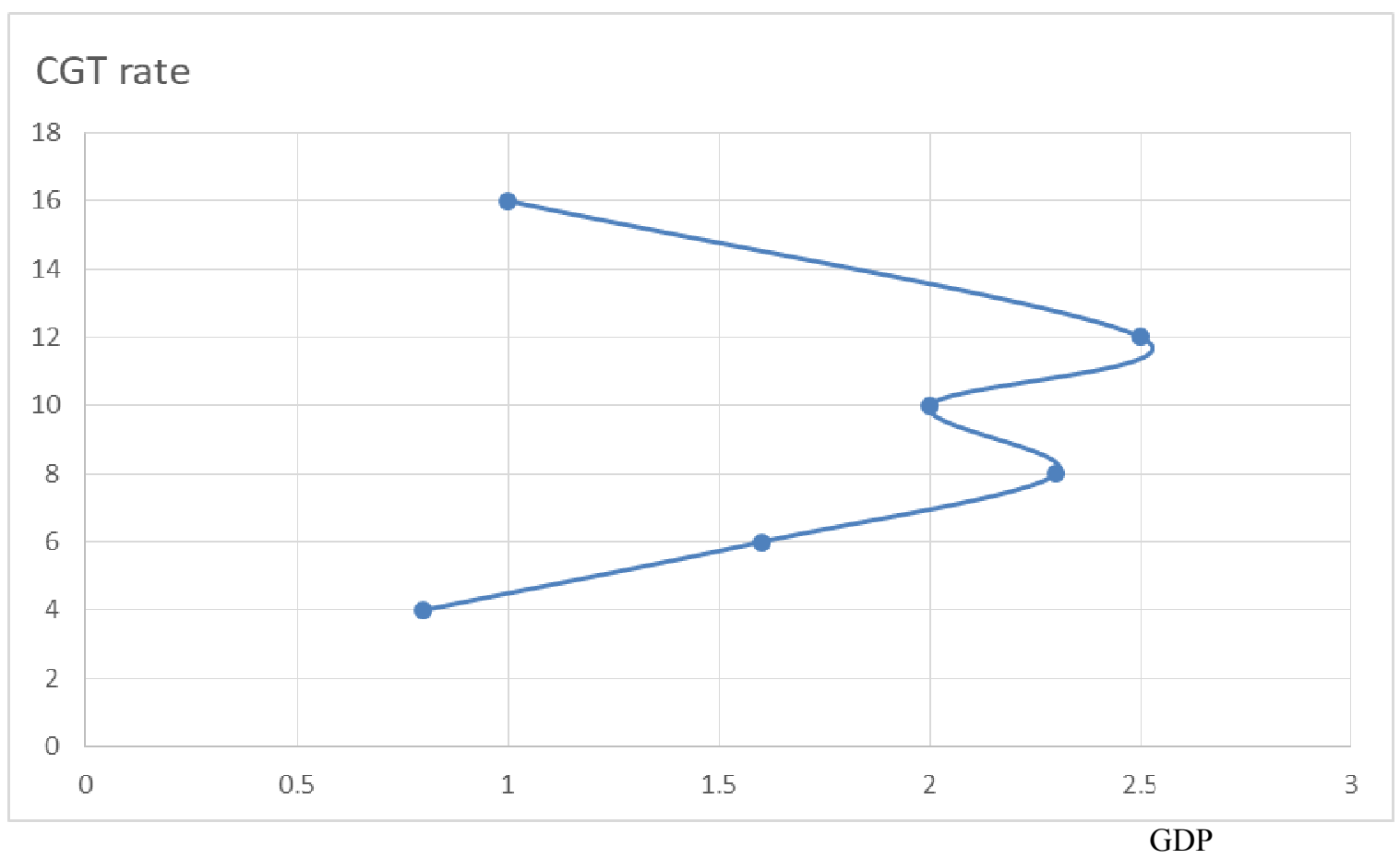

Source: Researchers' Relationship between Capital Gains Tax Rate and Gross Domestic Products 


\subsubsection{Conceptual framework of Capital Gains Tax on Investment, Social and Economic Development in} Nigeria

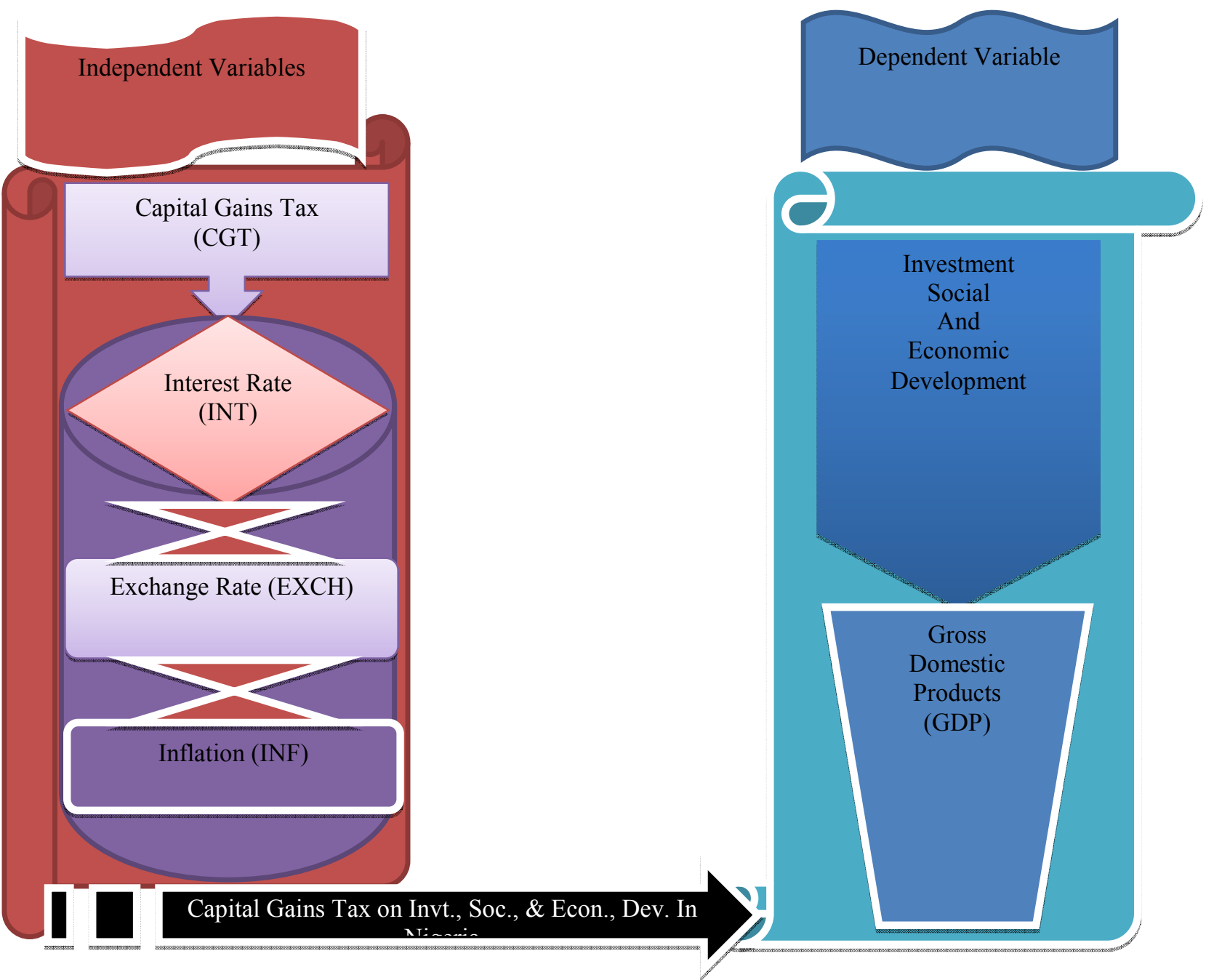

Source: Researchers’ Capital Gains Tax on Investment, Social and Economic Development in Nigeria

\subsection{Methodology}

The researcher made use of secondary data derived from Central Bank of Nigeria (CBN) Statistical Bulletin, and Nigeria's Federal Inland Revenue Service Bulletin from 2007 to 2017. This Model evaluated the impact of Capital Gains Tax (CGT) on Investment, Social and Economic Development in Nigeria. Regression Analysis technique is used as a tool to measure the effect of independent variables on dependent variable, while Pearson Product Moment Correlation for the relationship between the dependent variable and independent variables.

Note: Investment, Social and Economic Development (proxied by GDP) are the dependent variable, while CGT, interest rate, exchange rate and inflation are independent variables.

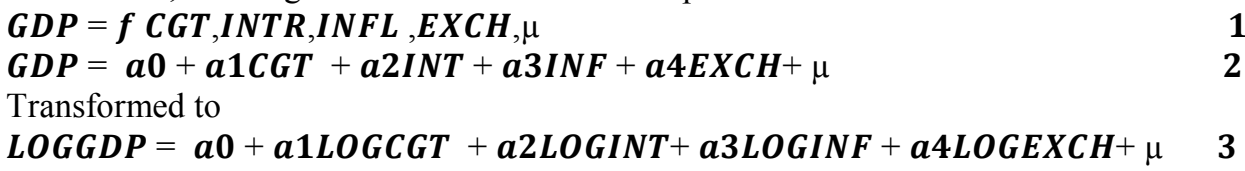

Where $\mathrm{n}=$ no of observations $\mathrm{r}=$ Coefficient of correlation showing the degree of relationship between the dependent variable and independent variable.

Where:

LOG GDP - Log of Gross Domestic Products

LOG CGT - Log of Capital Gain Tax

LOG INT - Log of Interest rate

LOG INF - Log of Inflation rate 
LOG EXCH - Log of exchange rate

$\boldsymbol{\mu}$

- error term

\subsection{Results}

The data obtained from the CBN Statistics Bulletin 2013 were analyzed below:

Table 1: Descriptive Analysis of the Significance of Components of investment, Social and Economic Development

\begin{tabular}{|l|c|c|c|c|c|}
\hline Variable & Obs & Mean & Std. Dev. & Minimum & Maximum \\
\hline GDP & 10 & $1.93 \mathrm{e}+08$ & $2.72 \mathrm{e}+08$ & $1.86 \mathrm{e}+07$ & $6.72 \mathrm{e}+08$ \\
\hline CGT & 10 & 5924415 & 6961745 & 110460.8 & $1.68 \mathrm{e}+07$ \\
\hline Interest & 10 & 10.996 & 5.295439 & 5.62 & 24.4 \\
\hline Exch. Rate & 10 & 150.549 & 23.42363 & 120.97 & 199 \\
\hline Inflation & 10 & 10.042 & 2.560615 & 5.4 & 13.72 \\
\hline
\end{tabular}

Source: Researchers' Descriptive Analysis using STATA Version 11

The above table shows that investment, social and economic development as the dependent variable had a mean value of $1.93 \mathrm{e}+08$ with a standard deviation of $2.72 \mathrm{e}+08$, and it had a maximum value of $6.72 \mathrm{e}+08$ and a minimum value of 1.86e + 07. Capital Gain Tax had a mean of 5924415 and standard deviation of 6961745 with positive maximum and minimum value of $1.68 \mathrm{e}+07$ and 110460.8 respectively, which signifies that for every 1 per cent increase in Capital Gain Tax, investment, social and economic development increases by 5.9 per cent, this implies that there is a positive relationship between investment, social and economic development and capital gains tax. Also, interest rate, exchange rate and inflation have the mean values of 10.996, 150.549 and 10.042 respectively with standard deviations of $5.295439,2.560615$, and 23.42363 with positive maximum values of 24.4, 13.72 and 199 with positive minimum values of 5.62, 5.4 and 120.97 respectively. This indicates that for every 1 per cent increase in interest rate, exchange rate and inflation, there would be an increase in investment, social and economic development in Nigeria.

Consequently, it could be stated from the analysis that there is a positive relationship between the variables (i.e dependent and independent variables). One could therefore, reject the null hypothesis and accept the alternative hypothesis that is there is a positive significant relationship between Capital Gains Tax and Investment, Social and Economic Development in Nigeria.

Table 2: The impact of CGT on investment, social and economic development in Nigeria

\begin{tabular}{|c|c|c|c|c|c|c|}
\hline $\begin{array}{l}\text { Independent } \\
\text { variable }\end{array}$ & $\begin{array}{l}\text { Dependent } \\
\text { variables }\end{array}$ & Coefficient & $\begin{array}{l}\text { Standard } \\
\text { Error }\end{array}$ & $\mathrm{T}$ & $\mathrm{P}>\mathrm{IT}$ & $\{95 \%$ Conf. Interval \\
\hline LOG GDP & LOG CGT & .5622271 & .2367213 & 3.98 & 0.014 & $.0462843 \quad 1.170739$ \\
\hline & LOG INTR & .4465809 & .6446778 & 0.69 & 0.519 & 1.210616 \\
\hline & LOG INFL & -1.790332 & .8568845 & 2.99 & 0.021 & 3.993023 \\
\hline & LOG EXCH & .8364850 & 2.766433 & 4.03 & 0.002 & $4.274858 \quad 9.947828$ \\
\hline & constant & -1.353543 & 10.42698 & 8.13 & 0.000 & $-28.15696 \quad 25.44987$ \\
\hline $\begin{array}{l}\text { R-squared } \\
0.6909\end{array}$ & $\begin{array}{l}\text { Adj } \quad \text { R-squared } \\
=0.6036\end{array}$ & \multicolumn{2}{|c|}{$\frac{\text { Prob }>F=0.0007}{\text { MSE }=.65818}$ Root } & \multicolumn{3}{|c|}{$\mathrm{F}(4,5)=110.21$} \\
\hline
\end{tabular}

Source: Researchers' computation

As seen above in table 2, an increase of 1 per cent in Capital Gain Tax (LOG CGT) ups Economic development (LOG GDP) by 0.5 per cent. This indicates a positive effect of CGT on LOG GDP. The result is also significant $(\mathrm{P}>\mid \mathrm{t}=0.014 ; \mathrm{P}<0.05) .1$ per cent rise in interest rate (LOG INTR) jerks-up LOG GDP by 0.44 per cent. This indicates that the relationship between LOG INTR and LOG GDP is positive suggesting that if LOG INTR increases LOG GDP also increases. Conversely, 1 per cent increase in the Inflation rate (LOG INFL) reduces LOG GDP by 0.6 per cent. This suggests a negative effect of LOG INFL on LOG GDP. The result is also significant. Furthermore, 1 per cent increase in Exchange rate (LOG EXCH) increases LOG GDP by 0.8 per cent. This reveals a positive significant effect of LOG EXCH on LOG GDP. This is suggesting that if LOG $\mathrm{EXCH}$ in Nigeria increases, LOG GDP also increases.

Given R2 as 0.6909 (69 per cent) with the high value of adjusted R2 as 60.3 per cent, it signifies that the independent variables incorporated into this model were able to determine effect of capital gains tax on Economic growth by 60 per cent. The $\mathrm{F}$ and probability statistics (Prob $>\mathrm{F}=0.0007$ ) also confirmed the significance of this model. From the decision rule above, because the p-value for the alternative hypothesis equals 0.0007 which is less than 0.05 , therefore the null hypothesis is rejected while the alternative hypothesis is upheld, that is there is significant effect of Capital Gain Tax on investment, Social and Economic Development in Nigeria. 


\subsection{Conclusion}

The objective of this study is to set out the impact of Capital Gains Tax on Investment, Social and Economic Development of Nigeria. In view of the foregoing, the analysis conducted revealed that there is a positive effect of Capital Gains Tax on investment, social and economic development in Nigeria. All other variables have positive effect on investment, social and economic development, except inflation rate which has negative significant effect on investment, social and economic development in Nigeria. Additionally, it should be noted that interest rate and inflation rate have insignificant relationship with economic development in Nigeria. Capital gains tax and exchange rate have positive and significant correlation with economic growth; that is the more the Capital gains tax and exchange rate, the more will be improvement in the level of Investment, Social and Economic Development in Nigeria.

In conclusion, capital gains tax had positive significant impact on investment, social and economic development in Nigeria but the level of significance is quite low. It is therefore recommended that government should increase the CGT tax rate so as to improve the revenue accruable to government. However, care must be exercised not to increase it beyond tolerable limit as this could spring forth the negative effect of dissention or demotivation of entrepreneurship thereby reducing the country's gross domestic products (GDP). Government should strive to arrive at an optimal tax level on CGT which would simultaneously boost tax revenue and GDP at the same time. FIRS and their State counterparts should also strive to drag into the tax-net other inefficient assets and properties such as houses and bare-lands which hitherto had been suffering from tax evasion despite the magnitude billions exchanging hands in that dark-trade sector. Government should adopt decisive mechanism in the mode of capital gain tax collection in order to inhibit the leakages so that the capital gain tax generated will not be siphoned to unscrupulous purse (Fasina \& Adegbite, 2016). By increasing the capital gains tax rate (at least up-to the optimal level), tax revenues would increase, also entrepreneurial and industrial drive would be sustained which would boost investment, social and economic development in Nigeria.

\section{References}

AL-Robeidi, M. A. (2000). Tax Accounting, Pp 48-52.

American Council for Capital Formation. Testimony submitted for the record for the hearing on "Tax Reform and the Tax Treatment of Capital Gains"

Australian Taxation Office, (2018). Guide to capital gains tax.

Bhatia, H. L. (2002). Public Finance, preceding source, 23", p. 40-41.

Capital Gains Tax Act CAP C1 of the Laws of the Federation of Nigeria (LFN) 2004 (as amended)

Constitution of the Federal Republic of Nigeria, (1999).

Central Bank of Nigeria (CBN), (2018). Annual Statistical Bulletin.

Fasina, H. T. \& Adegbite, T. A. (2016). The assessment of the impact of capital gain tax on economic growth in Nigeria. International Journal in Management and Social Science (Impact Factor- 5.276). Vol.04 Issue-08, ISSN: 2321-1784

Federal Inland Revenue Service Bulletin, (2018).

Henry Campbell Black (1997). Black's law dictionary, Abridged $6^{\text {th }}$ Edition, centennial, Trade PB, 75877

Institute of Chartered Accountants of Nigeria (ICAN) Pack, (2014). Taxation

Joint Hearing House Committee on Ways and Means and Senate Committee on Finance September 20, 2012

Kulkami, M. (2001). Business Taxation and Auditing, preceding source, P.3.

Miller, A \& Oats, L., (2006). Principles of International Taxation. London, U.K. Tottel Publishing.

Nairametrics (2013). How to Compute Capital Gains Tax In Nigeria - Beginners Guide. http://nairametrics.com/how-to-compute-capital-gains-tax-in-nigeria-beginners-guide/

Ojo, S. (2009). "Fundamental principles of Nigeria tax", 2nd Edition, Lagos, Sagribra Lax Publications.

Pınar Ç. W. (2012). The Impact of Raising Tax Rates on Individual Capital Gains Economist American Council for Capital Formation. Testimony submitted for the record for the hearing on "Tax Reform and the Tax Treatment of Capital Gains" Joint Hearing House Committee on Ways and Means and Senate Committee on Finance.

PML (2017). Tax Legislation- An overview of the Capital Gains Tax Act. - http://www.pml.com.ng/taxlegislation-overview-capital-gains-tax-act/

Presidential Committee on National Tax Policy (2008). "Draft document on the National Tax Policy". Available from: http://www.scribd.com/doc/10063735/National-Tax-Policy-Draft-Updated. Accessed 05/07/10

Public Finance General Directorate (2009). The French tax system. Available from: http://www.impots.gouv.fr/portal/deploiement/p1/fichedescriptive_1006/fichedescriptive_1006.pdf. Accessed 20/03/10

Sundhmaram K.P.M \& Andley K.K. (2003). Public Finance “theory \& practice”, 16ed, Pp 56-57. 